\title{
EFFECT OF FEEDING POMEGRANATE (PUNICA GRANATUM L.) PEELS AND IT'S EXTRACT ON GROWTH PERFORMANCE AND CARCASS CHARACTERISTICS OF GROWING V-LINE MALE RABBITS
}

\author{
M. M. Nassrallah; Fatma E. Saba and M.A. Abo-Wardah \\ Animal Production Research Institute, Agricultural Research Center, Dokki, Giza, Egypt.
}

(Received 1/9/2016, Accepted 7/11/2016)

\section{SUMMARY}

\begin{abstract}
A total number of $45 \mathrm{~V}$-line rabbit males at 5 weeks of age and averaged about 846.25 to $861.25 \mathrm{~g}$ body weight were used in this study. Animals were distributed randomly into five experimental groups of 9 rabbits per each with three replicates ( 3 rabbits each). The $1^{\text {st }}$ rabbits group was served as a control group without any supplementation in diet or drinking water. The second and third groups were fed the basal diet supplemented with 1.0 and $1.5 \%$ pomegranate peel powder in the diet, respectively. Whereas, the fourth and fifth groups were fed the basal diet supplemented with 1.0 and $1.5 \%$ pomegranate peel extract in the drinking water, respectively. The experiment lasted for 8 weeks. The results obtained could be summarized as follows: rabbit males drinking pomegranate peel extract at different levels or fed pomegranate peel powder at different levels had significantly $(\mathrm{P} \leq 0.05)$ best values for live body weight and live body weight gain compared with the control rabbits. Rabbits fed $1 \%$ pomegranate peel powder consumed significantly $(\mathrm{P} \leq 0.05)$ feed more than other treatment groups or control group. Rabbit drinking 1.5\% pomegranate peel extract significantly $(\mathrm{P} \leq 0.05)$ improved feed conversion ratio followed by fed $1 \%$ pomegranate peel powder compared to other treatment groups or control group during whole experimental period. A significant $(\mathrm{P} \leq 0.05)$ increase in the digestion coefficient of organic matter with the addition of pomegranate peel extract or powder. Feeding basal diet plus pomegranate peel extract at high level causing lower $(\mathrm{P} \leq 0.05)$ significant the digestion coefficient of ether extract compared to other test diets. Either adding pomegranate peel in the form of powder or control diet led to an increase digest NFE coefficient compared to the addition of pomegranate peel extract. The results also showed the superiority of pomegranate peel extract compared to the addition of pomegranate peel powder to improve the utilization of energy in the form of TDN. Adding pomegranate peel extract was improved DCP significantly $(\mathrm{P} \leq 0.05)$ compared to the addition of PP powder and control diet. Adding pomegranate peel in powder form or in extract form of rabbits significantly $(\mathrm{P} \leq 0.05)$ increased concentration of total protein, globulin and total lipids comparing with control one. The best value of Economic Efficiency (EE) was recorded by group drinking $1.5 \%$ pomegranate peel extract. From the present study, it could be concluded that pomegranate peel in powder form by diet or in extract form by drinking water of rabbits improved the growth performance, digestibility coefficients, nutritive values, carcass characteristic and some blood constituents of $\mathrm{V}$-line growing rabbit males.
\end{abstract}

Keywords: pomegranate peel, rabbits, productive performance, digestibility coefficients, carcass and some blood constituents.

\section{INTRODUCTION}

Pomegranate (Punica granatum L.) is an important fruit crop of Egypt. Increasing agro-industrial units for producing pomegranate juice has led to increased processing of by-products including peels and seeds. These processes have led to production of high quantities of pomegranate byproduct biomass. Fresh pomegranate biomass contains high levels of moisture and soluble sugars (Shabtay et al., 2008). If it cannot use by farmers and industries as well as medical activities cause serious environmental problems. Pomegranate is one of the oldest known drugs. It is mentioned in the Ebers papyrus of Egypt written in about 1550 BC (Ross 1999). Moreover, it has been reported to have antimicrobial activity against a range of Gram positive and negative bacteria (McCarrell et al. 2008).

Pomegranate peel (PP) had the highest antioxidant activity in the peel (Li et al., 2006), especially, the most synthetic antioxidants have been restricted recently, mainly because of their possible carcinogenetic effect (Mhdavi and Salunkhe, 1995). Pomegranate is an important source of bioactive compounds and has been used for folk medicine for many centuries. Pomegranate attracts attention due to its apparent wound- 


\section{Nassraalah et al.}

healing properties (Chidambara et al., 2004), immunomodulatory activity (Gracious et al., 2001), antibacterial activity (Navarro et al., 1996) and antiatherosclerotic and antioxidative capacities (Tzulker et al., 2007). Antioxidative activity has often been associated with a decreased risk of various diseases and mortality (Huxley and Neil, 2003).

There free, the current study is an attempt to investigate the effect of using pomegranate peel extract via oral treatment or involving pomegranate peel powder in experimental diets on growth performance, digestibility coefficients, nutritive values, carcass characteristic and some blood constituents of V-line growing rabbit males.

\section{MATERIALS AND METHODS}

This experiment was conducted in the rabbitry of El-Gemeza research station, El-Gharbia Governorate animal production Research institute, Agricultural Research Center, Ministry of Agricultural, Egypt. During the period from May to July 2014 (The hot climate in Egypt).

\section{Experimental animals:}

A total number of $45 \mathrm{~V}$-line rabbit males at 5 weeks of age and averaged about 846.25 to $861.25 \mathrm{~g}$ body weight were used in this study. Animals were distributed randomly into five experimental groups of 9 rabbits per each with three replicates ( 3 rabbits each). The $1^{\text {st }}$ rabbits group was served as a control group without any supplementation in diet or drinking water. The second and third groups were fed the basal diet supplemented with 1.0 and $1.5 \%$ pomegranate peel powder in the diet, respectively. Whereas, the fourth and fifth groups were fed the basal diet supplemented with 1.0 and $1.5 \%$ pomegranate peel extract in the drinking water, respectively.

\section{Managements and feeding:}

Rabbits individually housed in galvanized wire cages $(30 \times 35 \times 40 \mathrm{~cm})$. Stainless steel nipples for drinking and feeders allowing recording individual feed intake for each rabbit were supplied for each cage. Rabbits of all groups were kept under the same managerial conditions. A period of 16 hours of day light was provided. Feed and water were available all time ad libitum during the experimental period. The basal ration that met all the requirements recommended by NRC (1990). The chemical composition of the basal diets and other treatment were presented in Table (1).

\section{Preparation of tested material}

Powder of pomegranate peel (PP) used in this research was obtained from local market, then fresh peel was washed with water and cut into little pieces then sun dried and ground. While, an equal extract of the pomegranate peel prepared by mashing in a proportion of $1: 2: 2$ (W peel/v water/v methanol) and left for about $48 \mathrm{hr}$ in refrigerator. The extract was filtered to remove the peel particles then concentrated under vacuum at $40: 50^{\circ} \mathrm{C}$ to get a concentrate, then stored at 3 to $4^{\circ} \mathrm{C}$ until used.

\section{Measurements:}

\section{Performance traits:}

Individual live body weight (LBW) was recorded at 5 wks of age and then weekly up to 13 wks of age. Live body weight gain (LBWG) was then calculated. Feed intake (FI) was recorded and feed conversion ratio (FCR) was calculated during the same previous intervals.

\section{Digestibility traits and nutritive value:}

At the end of the experiments, three male rabbits were used to determine the digestibility coefficients. The chemical composition of dietary treatment, and excreta were done according to the methods of A O A C (1996). The nutritive value of the experimental diets as DCP and TDN value were determined according to (Cheeke, 1987).

\section{Carcass traits:}

At the end of the experimental period at (13 weeks of age), three rabbits from each group were randomly taken, fasted for 12 hours, weighted individually and slaughtered to complete bleeding (Cheeke., 1987). After bleeding, rabbits were weighted and skinned. After slaughtering and skinning the carcasses were eviscerated. Relative weights of carcass, head and edible offal's (Giblets) included heart, 
liver, kidneys, spleen and lungs were removed and individually weighed. Empty weight was also recorded.

\section{Blood biochemical analysis:}

At 13 weeks of age (end of experiment) blood samples (about $6 \mathrm{ml}$ ) were collected from each slaughtered rabbit during exsanguinations in heparinized test tubes. The samples were centrifuged at 3000 rpm for 20 minutes. The separated plasma was stored in a deep freezer at $-20^{\circ} \mathrm{C}$ until assayed for total protein, albumen, globulin, total lipids and total cholesterol, according to the manufacture recommendations of commercial kits.

\section{Relative Economic efficiency:}

The relative economic efficiency of the experimental diets for the cost of feed required for producing one $\mathrm{kg}$ of body weight gain were calculated. The cost of the experimental diets was calculated according to the price of different ingredients prevailing in local market as well as the price of testing materials at the time of experimentation. Economic efficiency was calculated as a ratio between the return of weight gain and the cost of consumed feed.

\section{Statistical analysis:}

Data were subjected to one-way analysis of variance using SAS (2000). Differences among means were detected by using Duncan's multiple range test (Duncan, 1955). The percentage values were transferred to percentage angle using arcsine equation before subjected to statistical analysis, and then actual means are presented. The following model was used:

$$
\mathrm{Yij}=\mathrm{G}+\mathrm{Ti}+\mathrm{eij} \text {. }
$$

Where, Yij = observation for each dependent variable; $\mathrm{G}=$ General mean;

$\mathrm{Ti}=$ Treatment effects $(\mathrm{i}=1,2 \ldots$ and 5$) ;$ eij $=$ Random error.

Table (1): Composition and chemical analysis (\%) of the experimental diets for growth rabbits .

\begin{tabular}{lccccc}
\hline \multirow{2}{*}{ Ingredients } & \multicolumn{5}{c}{ Pomegranate in the experimental diet (\%) } \\
\cline { 2 - 5 } & Basal diet & PPL & PPH & PEL & PEH \\
\hline Clover hay (12\% CP) & 32.75 & 32.00 & 31.75 & 32.75 & 32.75 \\
Yellow corn & 17.80 & 17.80 & 17.80 & 17.80 & 17.80 \\
Soybean meal (44\%) & 15.20 & 15.25 & 15.20 & 15.20 & 15.20 \\
Wheat bran & 11.00 & 10.75 & 10.50 & 11.00 & 11.00 \\
Barley grain & 17.30 & 17.20 & 17.15 & 17.30 & 17.30 \\
Pomegranate peel & 00.00 & 1.00 & 1.50 & 00.00 & 00.00 \\
Molasses & 3.00 & 3.00 & 3.00 & 3.00 & 3.00 \\
Limestone & 0.4 & 0.4 & 0.4 & 0.4 & 0.4 \\
Salt & 0.35 & 0.35 & 0.35 & 0.35 & 0.35 \\
Dl- Methionine & 0.20 & 0.20 & 0.20 & 0.20 & 0.20 \\
L. Lysin & 0.10 & 0.10 & 0.10 & 0.10 & 0.10 \\
Di-calcium-Phosphate & 1.60 & 1.65 & 1.75 & 1.60 & 1.60 \\
Premix (vit.+Min.Mix & 0.30 & 0.30 & 0.30 & 0.30 & 0.30 \\
Total & 100.00 & 100.00 & 100.00 & 100.00 & 100.00 \\
Chemical analysis: & & & & & \\
Crude protein & 16.07 & 16.02 & 16.00 & 16.07 & 16.07 \\
DE (kcal/kg) & 2516 & 2509 & 2509 & 2516 & 2516 \\
Crude fiber & 13.49 & 13.51 & 13.52 & 13.49 & 13.49 \\
Ether extract & 3.47 & 3.44 & 3.44 & 3.47 & 3.47 \\
Calcium & 1.09 & 1.09 & 1.09 & 1.09 & 1.09 \\
Av. Phos. & 0.36 & 0.37 & 0.37 & 0.36 & 0.36 \\
Total Phos. & 0.67 & 0.68 & 0.68 & 0.67 & 0.67 \\
Lysin & 0.88 & 0.88 & 0.88 & 0.88 & 0.88 \\
Methionen & 0.44 & 0.44 & 0.44 & 0.44 & 0.44 \\
Meth. + Cys. & 0.70 & 0.70 & 0.70 & 0.70 & 0.70 \\
Na & 0.18 & 0.18 & 0.18 & 0.18 & 0.18 \\
\hline PPL = Pomegranate powder low level $(1 \%)$, & PPH & Pomegranate powder high level $(1.5 \%)$, \\
PEL= Pomegranate extracted low level $(1 \%)$ & & PEH & Pomegranate Extracted high level $(1.5 \%)$.
\end{tabular}




\section{RESULTS AND DISCUSSION}

\section{Growth Performance:}

Growth Performance parameters of growing rabbit males as influenced by dietary pomegranate peel powder or drinking pomegranate peel extract are illustrated in Table 2. Body weight of rabbits at 5 wks of age was nearly similar for treatment groups. At 9 wks of age, body weight of rabbits drinking $1 \%$ pomegranate peel extract (T4 group) was significantly $(\mathrm{P} \leq 0.05)$ increased compared to rabbits fed either 1 and 1.5\% pomegranate peel powder groups (T2 and T3 groups, respectively) or control group (T1 group). Similar trend was observed in body weight at the end of the experiment (13 wks of age) of rabbits drinking $1.5 \%$ pomegranate peel extract (T5 group) compared to rabbits fed $1.5 \%$ pomegranate peel powder (T3 group) or control group. Whoever, adding pomegranate peel in powder form or in extract form of growing rabbit males had significantly $(\mathrm{P} \leq 0.05)$ increased live body weight at 9 and 13 wks of age compared to control rabbits.

Body gain of growing rabbit males drinking different levels of pomegranate peel extract significantly $(\mathrm{P} \leq 0.5)$ increased as compared to dietary pomegranate peel powder or control group during period 5-9 wks of age, where rabbits fed pomegranate peel powder at different levels significantly $(\mathrm{P} \leq 0.05)$ showed the highest gain (546.25g) compared to control one during the previous period, while those fed pomegranate peel powder at $1 \%$ significantly $(\mathrm{P} \leq 0.05)$ showed the highest gain compared to drinking $1 \%$ pomegranate peel extract or control one during period 9-13 wks of age. During whole period 5-13 wks of age, adding pomegranate peel in powder form or in extract form of growing rabbit males had significantly $(\mathrm{P} \leq 0.05)$ increased body gain compared to control rabbits, the highest values $(901.25 \mathrm{~g})$ were recorded for rabbits drinking $1.5 \%$ pomegranate peel extract then those fed $1 \%$ pomegranate peel powder and drinking $1 \%$ pomegranate peel extract, without significant difference between them. (Table 2).

Rabbits drinking $1 \%$ pomegranate peel extract consumed significantly $(\mathrm{P} \leq 0.05)$ higher feeds as compared to other treatment groups or control group during 5-9 wks of age, while, during 9-13 wks of age rabbits drinking different levels of pomegranate peel extract consumed significantly $(\mathrm{P} \leq 0.05)$ less feeds as compared to those fed pomegranate peel powder at different levels groups or control group. However, during whole period (5-13 wks of age), rabbits fed 1\% pomegranate peel powder consumed significantly $(\mathrm{P} \leq 0.05)$ higher feeds as compared to other treatment groups or control group, which consumed approximately equal amount of feeds (Table 2).

Concerning the feed conversion ratio, adding pomegranate peel in powder form or in extract form significantly $(\mathrm{P} \leq 0.05)$ improved feed conversion ratio during 5-9, 9-13 wks of age and during whole period (5-13 wks of age) compared to the control group. Moreover, the best values of feed conversion ratio were recorded by rabbits drinking $1.5 \%$ pomegranate peel extract during all studied periods and during whole period (Table 2). These results are not accordance with those reported by Mahmoud et al., (2011) who found that rats fed on diets contained dry PP recorded the lowest final live weight, while those fed on control diet recorded the highest one.

Labib (2009) found that rats administered with different levels of pomegranate peel powder (5, 10 and $15 \%$ ) had a significant decrease in body weight gain than the control group. The reduction in feed intake may be due to the lower intestinal motility which led to a higher retention time of the digest in the gut as reported by (Garcia et al., 1999). (Li et al., 2006) demonstrated that the PP contained some compounds that influence palatability and consequently nutritive value, which include tannins, phenols, steroids, cyanogenic and alkaloids compounds. With conflict results had been found by (Shabaty et al., 2008); dietary supplementation with fresh pomegranate peels promoted significant increases in feed intake with a positive tendency toward increased weight gain of bull calves.( Makled et al., 2003) reported that bucks fed 0.25 and $0.50 \%$ tannic acid consumed less $(\mathrm{P} \leq 0.01)$ amount of feed than that of the control group (lowered by 33.13 and 23.50\%, respectively). Moreover, feed intake per buck was markedly decreased at the lower level of dietary tannic acid $(0.25 \%)$ than at the higher level $(0.50 \%)$. The difference between the current study and that the reported one by (Shabtay et al., 2008) that PP intake up to $20 \%$ of the total feed intake does not possess deleterious or positive effects on fattening ration intake of feedlot calves. The decrease in body weight may be attributed to the effect of condensed tannins or plyphenols in the PP which reflected on the significant decrease in feed intake and crude protein digestibility. Tannins are known to reduce mucosal secretion and make the intestinal mucosa more resistant (Scalbert, 1991and Tripathi, 1994). However the decreased rate of final body weight of rabbit bucks fed on diets containing different levels of PP does not reflect on any health hazards on rabbit bucks. Pomegranate is an important source of tannins punicalagin, anthocyanins and 
punicalin (Afaq et al., 2005), gallic and ellagic acids (Lansky and Newman, 2007) and also contains vitamin C (Turk et al., 2008). The antioxidant and free radical scavenging activity of pomegranate phenolic compounds (Rosenblat et al., 2006) and vitamin C (Sonmez et al., 2005) have been reported.

\section{Digestibility coefficients and nutritive values:}

The results obtained in Table (3) showed a significant $(\mathrm{P} \leq 0.05)$ increase in the digestion coefficient of organic matter with the addition of PP extract or powder. These results are a good agreement with ( Oliveira et al., 2010) who found that feeding PP increased DM, OM, or starch digestibility. Added of PP extract increased digestion coefficient of $\mathrm{CP}$ and $\mathrm{CF}$ significant $(\mathrm{P} \leq 0.05)$ for different levels of $\mathrm{PP}$ extract compared to the addition of PP powder. In general adding PPL, PEL and PEH leading to a significant $(\mathrm{P} \leq 0.05)$ increase in protein digestibility coefficient compared to control diet. ( Lebas, 1986) was reported that certain fiber sources (beet-root pulp, fruit pulp in general) are highly in CF digestibility, it varied from 60 to $80 \%$. The present of polyphenolic compounds could decrease the proteolytic activity and this compromise protein digestion (Oliveira et al., 2010). In the same concern, condensed tannins are considered to have positive effect on digestion, as it may protect protein and carbohydrate (Feizi et al., $2005 \mathrm{a}, \mathrm{b})$.

Feeding diets continent PP extract at high level causing lower $(\mathrm{P} \leq 0.05)$ significant the digestion coefficient of ether extract compared to other test diets. Add PP in the form of powder led to an increase digest NFE coefficient compared to the addition of PP extract, which also fell compared to control diet. The high level of PEH extract has led to increased food digestible compounds compared to the tested groups. The results also showed the superiority of PP extract compared to the addition of PP powder to improve the utilization of energy in the form of TDN. Add PP extract in drink water was improved of DCP significantly $(\mathrm{P} \leq 0.05)$ compared to the addition of PP powder and control diet. The positive effect of protein protection could affected on both of TDN, DCP and as these substances form insoluble complexes with proteins and carbohydrates lowering the nutritive value of any products contained tannins (Ferket and Middelton, 1999). In this respect, ( Akbar and Gupta, 1985) reported that tannin formulate proteintannin complexes in the gut which resulted in limiting dietary protein availability.

\section{Carcass characteristics:}

Data concerning carcass characteristics are presented in Table (4), it was noted that adding pomegranate peel in powder form or in extract form of rabbits had the significantly $(\mathrm{P} \leq 0.05)$ higher relative carcass weight and dressing percent compared to control one. However, the highest values in this respect were recorded by rabbits drinking $1.5 \%$ pomegranate peel extract, followed by rabbits drinking $1 \%$ pomegranate peel extract then rabbits fed different levels of pomegranate peel powder compared to control rabbits. In addition, rabbits drinking $1 \%$ pomegranate peel extract recorded the highest $(\mathrm{P} \leq 0.05)$ values relative lunges and head weights. While, the highest $(\mathrm{P} \leq 0.05)$ values of relative giblets and heart weights were recorded by rabbits fed $1 \%$ pomegranate peel powder. Moreover, rabbits drinking $1.5 \%$ pomegranate peel extract had significantly $(\mathrm{P} \leq 0.05)$ higher relative kidneys weight. On the other hand, there insignificantly differences due to treatments effect on relative spleen weight.

\section{Blood biochemical analysis:}

As shown in Table (5), adding pomegranate peel in powder form or in extract form of rabbits significantly $(\mathrm{P} \leq 0.05)$ increased concentration of total protein, globulin and total lipids comparing with control one. However, there were insignificantly differences due to forms of pomegranate peel supplementation on plasma total protein, globulin and total lipids concentrations. On the other hand, adding pomegranate peel in powder form or in extract form of rabbits did not affect plasma albumin and total cholesterol concentration. Several studies demonstrated a higher anti-oxidant activity of the PP in relation to the juice (Tzulker et al., 2007) mainly due to water-soluble polyphenols, anthocyanins and hydrolyzable tannins(Gil et al., 2000 and Zheng et al., 2009). Phenolic compounds attain their active antioxidant activity through free-radical scavenging activity (Andjelković et al., 2006) transition-metalchelating activity (Mukai et al. 2005) and/or singlet-oxygen quenching capacity (O'Grady et al., 2006). These mechanisms may explain the results obtained herein for the feed conversion which was characterized by higher anti-oxidative activity, in comparison with control.

\section{Economic efficiency $($ EEF $)$ :}

The effect of supplementing pomegranate peel in powder form or in extract form of rabbits on EEF is shown in Table 6. From economic viewpoint, it is clear that all pomegranate peel supplemented groups had better EEF values compared the control group (T1 group). The improvement in EFF as a result of using pomegranate peel in powder form or in extract form ranged between 54.94 and $98.49 \%$. Because of the increasing in LBW and the best FCR for rabbits drinking 1.5\% pomegranate peel extract (T5 group), 
the superior value for net revenue and EEF was calculated for these rabbits. It increased EEF by $98.49 \%$ as compared by control group. The increase in EEF which was exhibited by the rest of the experimental treatments valued about $76.61,54.94$ and $74.31 \%$ for T2, T3 and T4, respectively.

Table (2): Growth performance of growing V-line rabbits fed basal diet included pomegranate peel or supplemented with it's extracts by oral doses:

\begin{tabular}{|c|c|c|c|c|c|c|}
\hline \multirow{2}{*}{ Item } & \multicolumn{6}{|c|}{ Growth performance of growing v-line rabbit fed based diet } \\
\hline & Basal diet & PPL & PPH & PEL & PEH & MSE \\
\hline \multicolumn{7}{|c|}{ Live body weight $(\mathrm{g})$ : } \\
\hline $5 \mathrm{wk}$ & 846.25 & 857.50 & 855.00 & 852.22 & 861.25 & 13.691 \\
\hline $9 \mathrm{wk}$ & $1096.25^{\mathrm{d}}$ & $1205.00^{\mathrm{bc}}$ & $1175.00^{\mathrm{c}}$ & $1262.22^{\mathrm{a}}$ & $1246.25^{\mathrm{ab}}$ & 17.690 \\
\hline $13 \mathrm{wk}$ & $1581.25^{\mathrm{c}}$ & $1751.25^{\mathrm{ab}}$ & $1691.25^{\mathrm{b}}$ & $1724.44^{\mathrm{ab}}$ & $1762.50^{\mathrm{a}}$ & 21.216 \\
\hline \multicolumn{7}{|c|}{ Live body weight gain $(\mathrm{g})$ : } \\
\hline $5-9$ wk & $250.00^{c}$ & $347.50^{b}$ & $320.00^{\mathrm{b}}$ & $410.00^{\mathrm{a}}$ & $385.00^{\mathrm{a}}$ & 10.129 \\
\hline $9-13$ wk & $485.00^{\mathrm{bc}}$ & $546.25^{\mathrm{a}}$ & $516.25^{\mathrm{ab}}$ & $462.22^{c}$ & $516.25^{\mathrm{ab}}$ & 12.791 \\
\hline $5-13$ wk & $735.00^{\mathrm{c}}$ & $893.75^{\mathrm{a}}$ & $836.25^{\mathrm{b}}$ & $872.22^{\mathrm{ab}}$ & $901.25^{\mathrm{a}}$ & 14.839 \\
\hline \multicolumn{7}{|c|}{ Feed intake (g/rabbit): } \\
\hline $5-9 \mathrm{wk}$ & $961.25^{\mathrm{d}}$ & $1080.00^{\mathrm{c}}$ & $1080.00^{\mathrm{c}}$ & $1311.11^{\mathrm{a}}$ & $1176.25^{b}$ & 23.714 \\
\hline $9-13 \mathrm{wk}$ & $1870.00^{\mathrm{ab}}$ & $1980.00^{\mathrm{a}}$ & $1850.00^{\mathrm{b}}$ & $1574.44^{\mathrm{c}}$ & $1668.75^{\mathrm{c}}$ & 42.439 \\
\hline $5-13$ wk & $2831.25^{\mathrm{b}}$ & $3060.00^{\mathrm{a}}$ & $2930.00^{b}$ & $2885.56^{b}$ & $2845.00^{\mathrm{b}}$ & 43.990 \\
\hline \multicolumn{7}{|c|}{ Feed conversion ratio (feed intake, g/weight gain, g): } \\
\hline $5-9 \mathrm{wk}$ & $3.86^{\mathrm{a}}$ & $3.11^{\mathrm{cd}}$ & $3.39^{b}$ & $3.21^{\mathrm{c}}$ & $3.06^{\mathrm{d}}$ & 0.039 \\
\hline 9-13 wk & $3.86^{\mathrm{a}}$ & $3.63^{b}$ & $3.58^{b}$ & $3.41^{\mathrm{c}}$ & $3.23^{\mathrm{d}}$ & 0.031 \\
\hline $5-13 \mathrm{wk}$ & $3.86^{\mathrm{a}}$ & $3.42^{\mathrm{c}}$ & $3.51^{b}$ & $3.71^{b}$ & $3.16^{\mathrm{d}}$ & 0.026 \\
\hline
\end{tabular}

Table (3) : Digestibility coefficients and nutritive values of tested experimental diets

\begin{tabular}{|l|l|l|l|l|l|l|}
\hline Item & Basal diet & PPL & PPH & PEL & PEH & MSE \\
\hline DM & 72.60 & 72.52 & 73.01 & 72.98 & 73.02 & 0.187 \\
\hline OM & $72.88^{\mathrm{b}}$ & $73.74^{\mathrm{a}}$ & $73.96^{\mathrm{a}}$ & $73.85^{\mathrm{a}}$ & $73.89^{\mathrm{a}}$ & 0.131 \\
\hline CP & $69.87^{\mathrm{c}}$ & $71.00^{\mathrm{b}}$ & $68.97^{\mathrm{d}}$ & $72.01^{\mathrm{a}}$ & $72.42^{\mathrm{a}}$ & 0.229 \\
\hline CF & $44.16^{\mathrm{b}}$ & $44.21^{\mathrm{b}}$ & $44.53^{\mathrm{b}}$ & $46.29^{\mathrm{a}}$ & $45.98^{\mathrm{a}}$ & 0.146 \\
\hline EE & $96.23^{\mathrm{a}}$ & $96.12^{\mathrm{a}}$ & $95.97^{\mathrm{a}}$ & $95.86^{\mathrm{a}}$ & $93.57^{\mathrm{b}}$ & 0.173 \\
\hline NFE & $86.01^{\mathrm{a}}$ & $85.89^{\mathrm{a}}$ & $86.15^{\mathrm{a}}$ & $84.86^{\mathrm{b}}$ & $83.97^{\mathrm{c}}$ & 0.098 \\
\hline Nutritive values & \multicolumn{5}{|l}{} \\
\hline TDN & $76.92^{\mathrm{d}}$ & $77.91^{\mathrm{c}}$ & $77.82^{\mathrm{c}}$ & $80.12^{\mathrm{a}}$ & $78.91^{\mathrm{b}}$ & 0.128 \\
\hline DCP & $13.50^{\mathrm{b}}$ & $13.62^{\mathrm{b}}$ & $13.36^{\mathrm{b}}$ & $14.15^{\mathrm{a}}$ & $14.13^{\mathrm{a}}$ & 0.123 \\
\hline
\end{tabular}

${ }^{a, b}$ Means within each row have no similar letter $(s)$ are significantly different $(P \leq 0.05)$

$P P L=$ Pomegranate powder low level $(1 \%), \quad P P H=$ Pomegranate powder high level $(1.5 \%)$,

$P E L=$ Pomegranate extracted low level $(1 \%) \quad P E H=$ Pomegranate Extracted high level $(1.5 \%)$.

Table (4): Carcass characteristics of growing V- line rabbits as affected by feeding the experimental diets.

\begin{tabular}{lllllll}
\hline Item & Basal diet & PPL & PPH & PEL & PEH & MSE \\
\hline Carcass (\%) & $61.23^{\mathrm{e}}$ & $64.20^{\mathrm{d}}$ & $65.10^{\mathrm{c}}$ & $67.01^{\mathrm{b}}$ & $70.80^{\mathrm{a}}$ & 0.176 \\
Dressing (\%) & $72.30^{\mathrm{d}}$ & $74.92^{\mathrm{c}}$ & $74.89^{\mathrm{c}}$ & $75.78^{\mathrm{b}}$ & $76.61^{\mathrm{a}}$ & 0.164 \\
Giblets (\%) & $4.50^{\mathrm{b}}$ & $5.73^{\mathrm{a}}$ & $4.20^{\mathrm{b}}$ & $4.39^{\mathrm{b}}$ & $3.71^{\mathrm{c}}$ & 0.112 \\
Kidneys (\%) $_{\text {Heart (\%) }}$ & $0.850^{\mathrm{abc}}$ & $0.830^{\mathrm{bc}}$ & $0.810^{\mathrm{c}}$ & $0.860^{\mathrm{ab}}$ & $0.890^{\mathrm{a}}$ & 0.014 \\
Spleen (\%) & $0.500^{\mathrm{b}}$ & $0.590^{\mathrm{a}}$ & $0.550^{\mathrm{a}}$ & $0.430^{\mathrm{c}}$ & $0.400^{\mathrm{c}}$ & 0.014 \\
Lunges (\%) & $0.080^{\mathrm{ac}}$ & $0.090^{\mathrm{ab}}$ & $0.090^{\mathrm{a}}$ & 0.070 & 0.070 & 0.007 \\
Head (\%) & $0.660^{\mathrm{bc}}$ & $0.670^{\mathrm{ab}}$ & $0.640^{\mathrm{c}}$ & $0.690^{\mathrm{a}}$ & $0.670^{\mathrm{ab}}$ & 0.007 \\
\hline
\end{tabular}

\begin{tabular}{ccccc} 
Head $(\%)$ & $9.52^{\mathrm{c}}$ & $9.70^{\mathrm{b}}$ & $9.15^{\mathrm{d}}$ & $9.97^{\mathrm{a}}$ \\
\hline$a, b \ldots$. & Means within each row have no similar letter(s) are significantly different $(P \leq 0.05)$
\end{tabular}

$P P L=$ Pomegranate powder low level $(1 \%), \quad$ PPH = Pomegranate powder high level $(1.5 \%)$, 
Table (5): Some blood constituents of male V- line rabbits fed the experimental rations containing different levels of PP powder or supplemented PP extracts .

\begin{tabular}{|c|c|c|c|c|c|c|}
\hline \multirow{2}{*}{ Item } & \multicolumn{5}{|c|}{ Experimental treatments } & \multirow[t]{2}{*}{ MSE } \\
\hline & Basal diet & PPL & $\mathrm{PPH}$ & PEL & $\mathrm{PEH}$ & \\
\hline Total Protein $(\mathrm{g} / \mathrm{dl})$ & $5.40^{\mathrm{b}}$ & $5.79^{\mathrm{a}}$ & $5.92^{\mathrm{a}}$ & $5.99^{\mathrm{a}}$ & $5.99^{\mathrm{a}}$ & 0.08 \\
\hline Albumin $(\mathrm{g} / \mathrm{dl})$ & 3.03 & 3.06 & 3.14 & 3.12 & 3.15 & 0.10 \\
\hline Globulin $(\mathrm{g} / \mathrm{dl})$ & $2.37^{\mathrm{b}}$ & $2.72^{\mathrm{a}}$ & $2.77^{\mathrm{a}}$ & $2.92^{\mathrm{a}}$ & $2.83^{\mathrm{a}}$ & 0.06 \\
\hline Total lipids (g/dl) & $2.66^{\mathrm{b}}$ & $3.21^{\mathrm{a}}$ & $3.35^{\mathrm{a}}$ & $3.39^{\mathrm{a}}$ & $3.28^{\mathrm{a}}$ & 0.12 \\
\hline Total cholesterol(mg/dl) & 91.19 & 91.15 & 91.23 & 89.89 & 91.09 & 0.11 \\
\hline
\end{tabular}

Table (6): Effect of experimental treatments on the economic efficiency (EEF) of meat production ..

\begin{tabular}{|c|c|c|c|c|c|}
\hline Item & Basal diet & PPL & PPH & PEL & PEH \\
\hline Total feed consumption/rabbit $(\mathrm{kg})$ & 2.83 & 3.06 & 2.93 & 2.89 & 2.85 \\
\hline Price/kg feed (LE) & 2.63 & 2.62 & 2.61 & 2.64 & 2.64 \\
\hline Feed cost/rabbit (LE) & 7.44 & 8.00 & 7.64 & 7.61 & 7.52 \\
\hline Total cost $(\mathrm{LE})(\mathrm{A})$ & 29.44 & 30.00 & 29.64 & 29.61 & 29.52 \\
\hline Final body weight $(\mathrm{kg})$ & 1.58 & 1.75 & 1.69 & 1.72 & 1.76 \\
\hline Cost/kg body weight(LE) & 18.62 & 17.13 & 17.53 & 17.17 & 16.75 \\
\hline Total revenue(LE) (B) & 33.21 & 36.78 & 35.52 & 36.21 & 37.01 \\
\hline Net revenue $(\mathrm{LE})^{(1)}$ & 3.76 & 6.77 & 5.87 & 6.60 & 7.49 \\
\hline Economic efficiency ${ }^{(2)}$ & 12.78 & 22.58 & 19.81 & 22.29 & 25.38 \\
\hline Relative economic efficiency ${ }^{(3)}$ & 100 & 176.61 & 154.94 & 174.31 & 198.49 \\
\hline
\end{tabular}

(A) feed coast (Including fixed cost 22 LE/rabbit),

(B) Assuming that the selling price is (21 LE/Kg live weight).,

$\begin{array}{ll}\text { (1) Net revenue }=B-A . & \text { (2) Economic efficiency }=(\text { net revenue/ } A) * 100\end{array}$

(3) Relative Economic Efficiency = Economic efficiency of treatments other than the control / Economic efficiency of the control group $* 100$

\section{REFERENCES}

A O A C (1990). Official Method of Analysis 5th Edition, Washington Dc. USA, Association of official Analytical Chemist. pp. $66-88$.

Afaq, F., M. Saleem, C.G. Krueger, J.D. Reed, and H. Mukhtar, (2005). Anthocyanin- and hydrolysable tannin-rich pomegranate fruit extract modulates MAPK and NF-kappaB pathways and inhibits skin tumorigenesis in CD-1 mice. Int. J. Cancer, 113: 423-433.

Akbar, M.A. and P. C. Gupta (1985). Proximate composition tannin and mineral contents of different cultivars of various plant parts of subabul (Leucaena leucocephala). Ind. Animal Science, 55: 808812.

Andjelković, M., J. Van Camp, B. De Meulenaer, G. Depaemelaere, C. Socaciu, and M. Verloo, (2006). "Iron-Chelation Properties of Phenolic Acids Bearing Catechol and Galloyl Groups." Food Chemistry 98: 23-31.

- Cheek, P.R. (1987). Rabbit Feeding and Nutrition.Orlanto: Academic Press, Inc. Harcourt, Brace, Jovanovich, Publishers. Florida USA.

Chidambara, M.K.N., V.K Reddy, J.M. Veigas and U.D. Murthy (2004). Study on wound healing activity of Punica granatum peel. J. Med. Food, 7: 256-259.

Duncan, D.B.(1955). Multiple range and Multiple F-test Biometrics, 11: $1-42$.

Feizi, R.; A. Ghodrat Nama; M. Zahedifar Danesh; M. Mesgaran and M. Raisianzade (2005a). The influence of urea treatment on in vitro gas production of pomegranate peel. Proceeding of British Society of Animal Science. p. 223. 


\section{Nassraalah et al.}

Feizi, R. A.; Ghodrat Nama; M. Zahedifar Danesh; M. Mesgaran and M. Raisianzade (2005b). Apparent digestibility of pomegranate seed fed to sheep. Proceeding of British Society of Animal Science. p. 222.

Ferket, P.R. and T. Middelton (1999). Antinutrients in Feedstuff, Poultry International, March, 4655.

Garcia, J. ; R. Carabaño, and J. C. de Blas (1999). : Effect of fiber source on cell wall digestibility and rate of passage in rabbits. J. Anim. Sci., 77: 898-905.

Gil, M. I., F. A. Tomas-Barberan, B. Hess-Pierce, D. M. Holcroft and A. A. Kader, (2000). Antioxidant Activity of Pomegranate Juice and Its Relationship with Phenolic Composition and Processing. Journal of Agricultural Food Chemistry 48: 4581-9.

Gracious, R.R., S. Selvasubramanian and S. Jayasundar (2001). Immunomodulatory activity of Punica granatum in rabbits -a preliminary study. J. Ethnopharmacol., 78: 85-87. doi:10.1016/S03788741(01)00287-2.

Huxley, R.R. and H.A.W. Neil (2003). The relation between dietary flavonol intake and coronary heart disease mortality: a metaanalysis of prospective cohort studies. Eur. J. Clin. Nutr., 57: 904-908. doi:10.1038/sj.ejcn.1601624.

Labib, Fatma A. H. (2009). Effect of Pomegranate (Punica granatum) Peels and It's Extract on Obese Hypercholesterolemic Rats. Pakistan Journal of Nutrition 8 (8): 1251-1257.

Lansky, E.P. and R.A. Newman (2007). Punica granatum (pomegranate) and its potential for prevention and treatment of inflammation and cancer. J. Ethnopharmacol., 109: 177-206.

Lebas, F. (1986). The Rabbit: Husbandry, Health and Production. FAO Animal Production and Health series, No.21. Food and Agricultural Organization Rome, Italy.

Li, Y.; C. Guo; J. Yang; J. Wei; J. Xu and S. Cheng (2006). Evaluation of antioxidant properties of pomegranate peel extract in comparison with pomegranate pulp extract. Food Chem., 96(2): 254-260.

Mahmoud, Maha H.; S.S. Kassem; M. M. Abdel- Kader and F.A. El-Shobaki (2011). How to reduce weight and keep healthy. International journal of Academic research Vol. 3. No. 6. November, 2011, I Part.

Makled, M. N.; H. H. Sharara and H. Abd El-Fattah (2003). Tolerance of California rabbits to different levels of dietary tannic acid. Egyptian Journal of Poultry Science. 23 (III): 641-654.

McCarrell, E.M., S.W.J. Gould, M.D. Fielder, A.F. Kelly, W.E. Sankary and D.P Naughton (2008). Antimicrobial activities of pomegranate rind extracts: nhancement by addition of metal salts and vitamin C, BMC Complementary Altern. Med. 8:64.

Mhdavi, D.L. and D.K. Salunkhe (1995). Toxicological aspects of food antioxidant. In: Mhdavi D.L., Deshpande S.S., Salunkhe D.K. "Food Antioxidants", (Eds.) Marcel Dekker, New York.

Mukai, K., S. Nagai, and K. Ohara (2005). "Kinetic Study of the Quenching Reaction of Singlet Oxygen by Tea Catechins in Ethanol Solution.” Journal of Free Radical Biology Medicine 39: 752-61.

Navarro, V.; M.L. Villarreal ; G. Rojas and X. Lozoya (1996). Antimicrobial evaluation of some plants used in Mexican traditional medicine for the treatment of infectious diseases. J. Ethnopharmacol., 53: 143-147. doi:10.1016/0378-8741(96)01429-8

NRC (1990) National Research Coucil: Nutreint Requirements of Doestic Animals . Nutrient Requirements of Rabbits. 2 nd Ed. Reversed edition, National Academy of Science, Washingto, E. C. USA .

O’Grady, M. N., M. Maher, D. J. Troy, A. P. Moloney and J. P. Kerry, (2006). "An Assessment of Dietary Supplementation with Tea Catechins and Rosemary Extract on the Quality of Fresh Beef." Meat Science 73:132-43

Oliveira, R.A.; C.D. Narciso; R.S. Bisinotto; M.C. Perdomo; M.A. Ballou and M. Dreher (2010). Effects of feeding polyphenols from pomegranate extract on health, growth, nutrient digestion, and immunocompetence of calves. J. Dairy Sci., 93: 4280-4291.

Rosenblat, M., T. Hayek and M.Aviram, (2006). Anti-oxidative effects of pomegranate juice (PJ) consumption by diabetic patients on serum and on macrophages. Atherosclerosis, 187: 363-371. 
Ross, I. A. (1999) Medicinal plants of world. Humana press, Totowa, New Jersey. 273 - 281.

SAS (2000). Statistical Analysis system/Stat user's Guide, release 6.03. Ed., SAS Institute Inc., Cary Nc. USA, pp. 125.

Scalbert, A. (1991). Antimicrobial properties tannins.Phytochemistry 30: 3875-3883.

Shabtay, A.; H. Eitam Y. Tadmor; A. Orlov; A. Meir; P. Weinberg; Z.G., Weinberg; Y. Chen; A. Brosh; I. Izhaki and Z. Kerem (2008). Nutritive and antioxidative potential of fresh and stored pomegranate industrial byproduct as a novel beef cattle feed.J. Agric. Food Chem. 56: 10063-10070.

Sonmez, M., G. Turk and A. Yuce (2005). The effect of ascorbic acid supplementation on sperm quality, lipid peroxidation and testosterone levels of male Wistar rats. Theriogenology, 63: 2063-2072.

Tripathi, K. (1994). Essential of Medical Pharmacology. New Delhi, Jaypee Brothers Medical Publishers, p. 187.

Turk, G., M. Sonme, M. Aydin, A. Yuce, S. Gur, M. Yuksel, E.H. Aksu and H. Aksoy (2008). Effects of pomegranate juice consumption on sperm quality, spermatogenic cell density, antioxidant activity and testosterone level in male rats. Clin. Nutr., 27: 289-296.

Tzulker R., I. Glazer, I. Bar-Ilan, D. Holland M. Aviram and R. Amir (2007). Antioxidant activity, polyphenol content, and related compounds in different fruit juices and homogenates prepared from 29 different pomegranate accessions. J. Agr. Food Chem., 55: 9559-9570.

Zheng, G., L. Xu, P. Wua, H. Xie, Y. Jiang, F. Chen and X. Wei, (2009). Polyphenols from Longan Seeds and Their Radical-Scavenging Activity Food Chemistry 116: 433. 
تأثير التظذية على مسحوق قشر الرمان أو مستخلصه على الأداء الانتاجى ومواصفات الذبيحة لذكور الارانب

محم تحمد نصر الله ، فاطمة السيد سبع و تحما أنور خليل أبووردة معهز بحوث الانتاج الحيوانى ـ مركز البحوث النزراعية ـ الدقى ـ الجيزة.

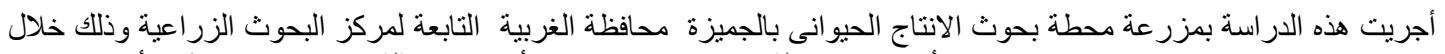

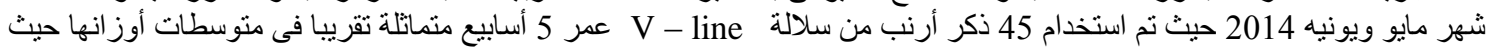

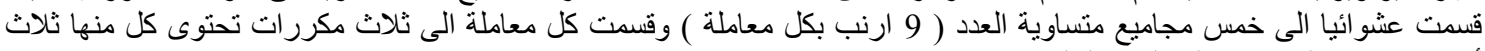

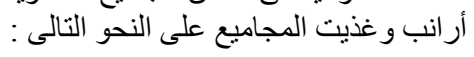
المجـــموعة الاولى : عليقة كنترول

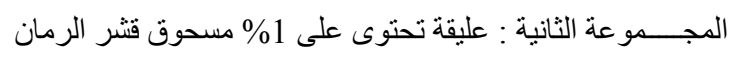

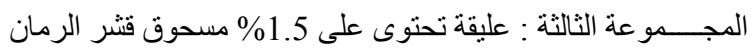

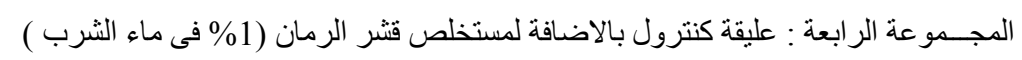

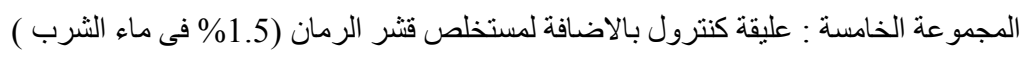

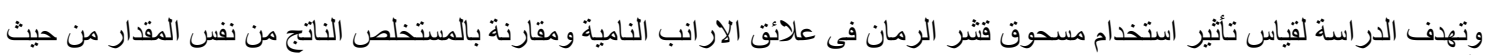

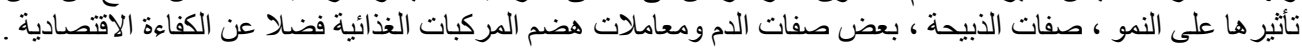
وبتحليل النتائج المتحصل عليها أحصائيا أنضح الاتى :

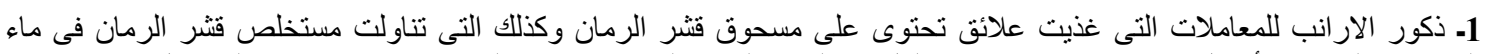

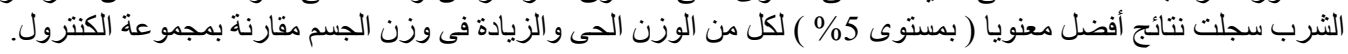

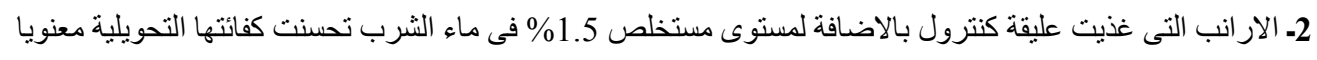
( بمستوى 5\% ) يليها فى ذلك نلك التى غذيت علائق تحتوى 1\% مسحوق قشتر الرمان مقارنة بـاقى المعاملات أو الكنترول

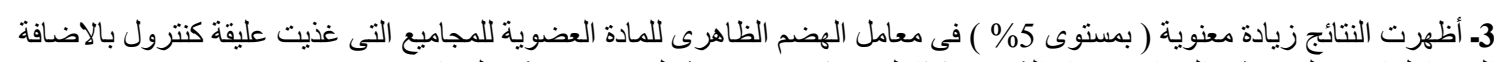

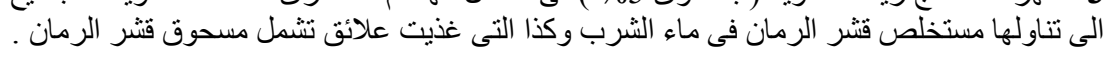

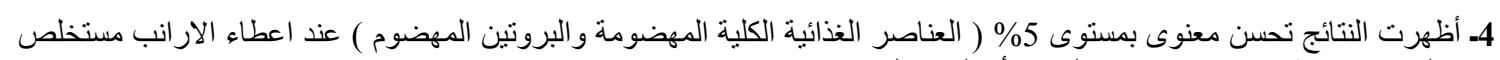
قشتر الرمان مقارنة باستخدام مسحوق الرمان أو الكتنرول

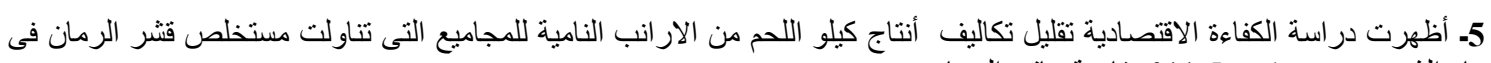

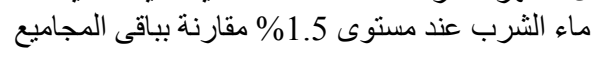
الخلاصة :

يمكن أضافة مسحوق قشر الرمان لعلائق الارانب أو أضافة مستخلص قشر الرمان لمياه الثرب لتحسين معدل النمو ومعامل الهضم الظاهرى للعناصر الغذائية ومواصفات الذيبحة ومكونات الأدم. 